\title{
LEAF GAS EXCHANGE IN TWO DWARF COCONUT GENOTYPES IN THE SOUTHEAST OF BAHIA STATE, BRAZIL.
}

By

Gomes, F.P., Mielke, M.S., Almeida, A. F. and Muniz, W. S. ${ }^{1}$

\begin{abstract}
Net photosynthetic $(A)$ and leaf transpiration $(E)$ rates and stomatal conductance to water vapour ( $g s)$ of Malayan Yellow Dwarf (MYD) and Brazilian Green Dwarf (BGD) coconut accessions (Cocos nucifera var. 'nana' L.) were studied and discussed in terms of the technical aspects related to light-response curves in field conditions. Measurements of gas exchange were performed during four days, in April and may 2000, at the Cocoa Research Center Experimental Station (Una - BA, Brazil). The A, gs and E parameters were significantly $(P<0.05)$ different between the two genotypes. The mean maximum values of $A, g s$ and $E$ were 10.4 and $12.0 \mu \mathrm{mol} \mathrm{CO}_{2} \mathrm{~m}^{-2} \mathrm{~s}^{-1}, 0.21$ and $0.35 \mathrm{~mol} \mathrm{H}_{2} \mathrm{O}$ $m^{-2} s^{-1}$ and 3.07 and $3.69 \mathrm{mmol} \mathrm{m}^{-2} \mathrm{~s}^{-1}$ for MYD and BGD, respectively. For both genotypes a good fitting of the light-
\end{abstract}


response curve models were obtained, indicating that $A$ and gs were dependent of the photosynthetically active radiation incident on leaf surface (Qi), in spite of high genotipic variation. Interesting results were achieved when an empirical multiplicative model was used. The model relating A or gs with Qi and with leaf-to-air water vapour pressure deficit inside the chamber $\left(V P D_{L}\right)$ was tested for both genotypes and showed a negative influence of the latter on the stomatal behavior and consequently on A. Such effect was more pronounced in BGD than in MYD. These and others relationships involving leaf gas exchange and microclimatic variables in coconut palm trees are discussed

\section{INTRODUCTION}

The southeast area of Bahia State (Brazil), traditionally known as "cacaueira", is currently facing an unprecedented economical and social crisis, mostly due to the low international prices of the cocoa beans associated with the high incidence of the fungal "witches broom" disease in their crops. The necessity to develop other agricultural products in this region has been demanding a lot of information, mainly with respect to the yield potential of these alternative crops under a changing environment. In this sense, the cultivation of dwarf coconut genotypes for the production of

1 Universidade Estadual de Santa Cruz, Department of Biological Sciences,Rod. Ilhéus-Itabuna, Km 16, Ilhéus, Bahia, Brazil, CEP 
tender coconut water has been turned into a profitable and widespread activity for the farmers of this and other Brazilian States.

The understanding of the physiological responses of the coconut to the environmental conditions is relevant when the objective is to reach high yields in different field conditions. Then, it is essential to identify the responses of the gas exchange parameters to environmental variables. Some information about responses of physiological parameters of coconut palm trees to environmental factors in Brazilian conditions are available for tall (Passos and Silva, 1990, Prado et al., 2001) and dwarf varieties (Cintra et al., 1992; Passos et al., 1999). In other countries, studies concerning photosynthesis and respiration (Mathew and Ramadasan, 1974, 1975; Shivashankar et al., 1982; Jayasekara and Jayasekara, 1995), water relations (Kasturi Bai et al., 1988; Shivashankar et al., 1991; Rajagopal and Kasturi Bai, 1999) and leaf gas exchange (Kasturi Bai et al., 1997; Braconnier, 1998) are also of great relevance for the management of tall varieties and hybrids.

The use of mathematical models to estimate stomatal and nonstomatal limitations of photosynthesis have been developed (Mansfield and Davies, 1985; Ball et al., 1987; Leuning, 1990; Thornley and Johnson, 1990). These models provide a simplified description of a real system, thereby generating information that would otherwise remain hidden and would help predictions of the results to a reasonable extent (Iqbal, et al., 1997). The use of empirical mathematical models, adjusted from simultaneous

45650-000. Correspondence to: gomes@uesc.br 
measurements of gas exchange and environmental variables, allows one to approach the effects of those variable on gas exchange (Jarvis, 1976; Yang, et al., 1998; Day, 2000; Mielke et al., 2000).

The aim of this work was to study the leaf gas exchange parameters in two adult dwarf coconut genotypes growing in the southeast of Bahia State, Brazil, and to test the effectiveness of an empirical mathematical model that explains the responses of photosynthesis and stomatal conductance to water vapour to the light and to the leaf-to-air water vapour pressure deficit.

\section{MATERIALS AND METHODS}

The measurements were performed during the following four days $04 / 28,05 / 12$ and 25 , and 06/02 of the year 2000, always from 8:00 to 15:00 h, in the Cocoa Research Center Experimental Station, in Una-BA $\left(15^{\circ} 15^{\prime} 45^{\prime \prime} \mathrm{S}, 3^{\circ} 05^{\prime} 49^{\prime \prime} \mathrm{W}, 105\right.$ masl). The site of study employed included plants of cocoa (Theobroma cacao L.) and 'cupuaçu' (T. grandiflorum L.) as accessory species, and plants of the dwarf coconut (Cocos nucifera var. nana L., Palmae) genotypes Malayan Yellow Dwarf (MYD) or Brazilian Green Dwarf (BGD) as the main culture, in an 'intercrop' design. The times of measurements chosen aimed to verify the effects of leaf-to-air water vapour pressure deficit on the gas exchange parameters.

Light-response curves were obtained using a portable photosynthesis system LI-6400 (Li-Cor Inc., Nebraska, USA) equipped with an artificial light source 6400-02B RedBlue \#SI-925. The "Light curve" routine of the software OPEN 3.3, in seven levels 
of photosyntheticaly active radiation $\left(Q_{i}, \mu \mathrm{mol}\right.$ photons $\left.\mathrm{m}^{-2} \mathrm{~s}^{-1}\right), 50$, 100, 200, 400, 800, 1300 and 1600, in a decreasing order, was set. Each reading was recorded in an interval of time from 120 (minimum) to $150 \mathrm{~s}$ (maximum). A flow rate of $400 \mu \mathrm{mol} \mathrm{s}{ }^{-1}$ was set, with a maximum coefficient of variation (C.V.) allowed of $1 \%$, although most of readings has been saved with C.V. $<0.8 \%$.

The rates of net photosynthesis $\left(A, \mu \mathrm{mol} \mathrm{CO} \mathrm{C}^{-2} \mathrm{~s}^{-1}\right)$ and leaf transpiration $\left(E, \mathrm{mmol} \mathrm{H}_{2} \mathrm{O} \mathrm{m}^{-2} \mathrm{~s}^{-1}\right)$, and the stomatal conductance to water vapour $\left(g s, \mathrm{~mol} \mathrm{H}_{2} \mathrm{O} \mathrm{m}^{-2} \mathrm{~s}^{-1}\right)$ were estimated from values of $\mathrm{CO}_{2}$ assimilation and of variation in the air humidity inside de chamber, both determined by the infrared gas analizer (IRGA) of the portable photosynthesis system. The instantaneous water use efficiency (WUEi, $\mu \mathrm{mol} \mathrm{CO}_{2}$ mmol $\mathrm{H}_{2} \mathrm{O}^{-1}$ ) was calculated by the quotient between $A$ and $E$, for each reading. The rate of dark respiration $\left(R d, \mu \mathrm{mol} \mathrm{CO} \mathrm{C}^{-2} \mathrm{~s}^{-1}\right)$ corresponded to values of $A$ when $Q_{i}=0 \mu \mathrm{mol}$ photons $\mathrm{m}^{-2} \mathrm{~s}^{-1}$. Values of internal $\left(C_{i}, \mu \mathrm{mol} \mathrm{mol}{ }^{-1}\right)$ and

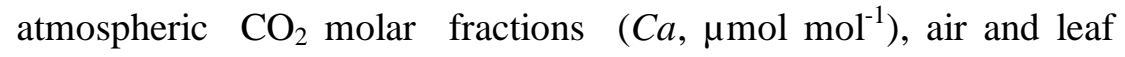
temperatures ( $\mathrm{Ta}$ and $T_{L},{ }^{\circ} \mathrm{C}$ ) and leaf-to-air water vapour pressure deficit inside the chamber $\left(V P D_{L}, \mathrm{kPa}\right)$ were supplied or calculated by the software of the equipment.

Eleven plants of MYD and eight plants of BGD, with 5 years old and 4 to $5 \mathrm{~m}$ of height were used for the estimation of the light response curves. In each plant, the measurements were made in one leaflet of the middle portion of the rank 9 leaf, counted from top down. In order to access the leaf let with the equipment, were used fixed and mobile towers. 
For the maximum values of gas exchange, were considered only the readings obtained when $Q_{i} ? 800 \mu \mathrm{mol}$ photons $\mathrm{m}^{-2} \mathrm{~s}^{-1}$. Comparisons were accomplished between the means of measured microclimatic variables and between the mean maximum values of the leaf gas exchange variables, using the Turkey's procedure $(P<$ $0.05)$.

The parameters derived from the light-response curves were obtained by applying empirical multiplicative models adjusted by the non-linear estimates routine of Statistica for windows, version 5.0 (StatSoft, Inc., 1995). The model y $=f\left(Q_{i}\right) f\left(V P D_{L}\right)$ was used, where y correspond to $A$ or $g s$, following the equations:

$$
\begin{aligned}
& \left.A=\left(\left(A_{\max } ?_{A} Q i\right) /\left(A_{\max }+?_{A} Q i\right)\right)\left(1-V P D_{L} / V P D_{O}\right)\right)-R d \\
& g s=\left(\left(g s_{\max } x ?_{g s} Q i\right) /\left(g s_{\max }+?_{g s} Q i\right)\right)\left(1-V P D_{L} / V P D_{O}\right)
\end{aligned}
$$

where $A_{\max }$ is the light saturated rate of net photosynthesis $\left(\mu \mathrm{mol} \mathrm{CO}_{2}\right.$ $\left.\mathrm{m}^{-2} \mathrm{~s}^{-1}\right), ?_{A}$ is the apparent quantum efficiency of photosynthesis $\left(\mu \mathrm{mol} \mathrm{CO}_{2} \mu \mathrm{mol}\right.$ photons $\left.{ }^{-1}\right), g s_{\max }$ is the light saturated stomatal conductance to water vapour $\left(\mathrm{mol} \mathrm{H}_{2} \mathrm{O} \mathrm{m} \mathrm{m}^{-2} \mathrm{~s}^{-1}\right), ?_{g s}$ is the apparent quantum efficiency of stomatal conductance (mol $\mathrm{H}_{2} \mathrm{O} \mu$ mol photons ${ }^{-}$ ${ }^{1}$ ) and $V P D_{o}$ is the values of $V P D_{L}$ when $A($ or $g s)=0$.

\section{RESULTS AND DISCUSSION}

The microclimatic parameters were highly variable for the two genotypes (Table 1) as a consequence of the measurements being taken in different days and times of the day. $V P D_{L}$, was significantly higher at the days of MYD measurements. Ta and $T f$ did not differ 
significantly. Such microclimatic situation was providential once one of the goals of this work was to verify the responses of $A$ and $g s$ to $V P D_{L}$.

Significant differences between the two genotypes were observed for the maximum ( $Q i$ ? $800 \mu \mathrm{mol}$ photons $\left.\mathrm{m}^{-2} \mathrm{~s}^{-1}\right)$ values of $A$ and $g s$ (Table 2). The BGD genotype showed higher values of $A$ $\left(12.0 \mu \mathrm{mol} \mathrm{CO} \mathrm{m}^{-2} \mathrm{~s}^{-1}\right)$, gs $\left(0.35 \mathrm{~mol} \mathrm{H}_{2} \mathrm{O} \mathrm{m}^{-2} \mathrm{~s}^{-1}\right), E(3.69 \mathrm{mmol}$ $\mathrm{H}_{2} \mathrm{O} \mathrm{m}^{-2} \mathrm{~s}^{-1}$ ) and $\mathrm{Ci} / \mathrm{Ca}(0.75)$, whereas the MYD genotype showed high values of $\operatorname{WUEi}(3,98)$ and $R d\left(1.84 \mu \mathrm{mol} \mathrm{CO} \mathrm{Cm}^{-2} \mathrm{~s}^{-1}\right)$. The maximum values of $A$ obtained in this study were higher than others obtained for tall and hybrid coconut trees (Kasturi Bai et al., 1997; Braconnier, 1998). For example, Kasturi Bai et al. (1997) found values of $A$ ranging from 6.48 to $8.26 \mu \mathrm{mol} \mathrm{CO}_{2} \mathrm{~m}^{-2} \mathrm{~s}^{-1}$ for nonirrigated and irrigated plants, respectively. On the other hand, values of $g s$ are lower than that obtained by Passos et al. (1999). These authors observed values of $0.48,0.67$ and $0.32 \mathrm{~mol} \mathrm{H}_{2} \mathrm{O} \mathrm{m}^{-2} \mathrm{~s}^{-1}$ for the $g s$ of Jiqui Green Dwarf, Malayan Yellow Dwarf and Malayan Red Dwarf, respectively. However, they used 10 years old plants and a steady state parameter (LI-COR 1600) to assess the parameters, which may help to explain the differences observed in our data.

The values of $\mathrm{Ci} / \mathrm{Ca}$ are good indicators for the stomatal limitation of photosynthesis at field conditions (Ehleringer and Cerling, 1995; Ishida et al., 1996; Mielke et al., 2000). The higher the values of $\mathrm{Ci} / \mathrm{Ca}$, the lower will be the stomatal limitation to the influx of $\mathrm{CO}_{2}$ and $W U E_{i}$ in the species. It was verified that the values of $\mathrm{Ci} / \mathrm{Ca}$ were relatively constant for $Q i$ levels ? $800 \mu \mathrm{mol}$ photons $\mathrm{m}^{-2}$ $\mathrm{s}^{-1}$ (Figure 1). The maximum values of $\mathrm{Ci} / \mathrm{Ca}$ and $\mathrm{WUEi}$ (Table 2) 
indicate the two genotypes seem relatively conservatives with respect to water use when compared with other tropical tree species (Hogan et al., 1995; Ishida et al., 1996). The significant differences observed for the values of $\mathrm{Ci} / \mathrm{Ca}$ between the two genotypes also suggest that the BGD is less conservative regarding water use than the MYD, although no significant differences in WUEi between the two genotypes were observed (Table 2). Nevertheless, both genotypes could be considered as being efficient with respect to the water use if compared with tall and hybrids coconut genotypes. For example, Kasturi Bai et al. (1997) found values of $W U E$ ranging from 1.5 to $2.0 \mu \mathrm{mol} \mathrm{CO}_{2} \mathrm{mmol} \mathrm{H}_{2} \mathrm{O}^{-1}$ for one tall variety and for two hybrids. The WUE data obtained in this work are contrasting to those obtained by Kasturi Bai et al. (1996), in which the hybrids are more efficient than the varieties and also that the MYD genotype is less efficient than tall and hybrid genotypes.

The light response curves of $A$ and $g s$ indicate different tendencies between the two genotypes (Figure 2). For estimates of $A$, the tested models were corrected for the rate of dark respiration $(R d$, $\mu \mathrm{mol} \mathrm{CO}_{2} \mathrm{~m}^{-2} \mathrm{~s}^{-1}$ ), estimated when $Q i=0 \mu \mathrm{mol}$ photons $\mathrm{m}^{-2} \mathrm{~s}^{-1}$ (Table 2). Using the adjusted models, the values of compensation irradiance (?) were calculated as 48.4 and $32.5 \mu \mathrm{mol}$ photons $\mathrm{m}^{-2} \mathrm{~s}^{-1}$ for MYD and BGD, respectively. The parameters derived from the light response curves are shown in Table 3. For both genotypes, these parameters were higher than the limits found for other tree species. For example, Barker et al. (1997), working with ten tropical tree species previously acclimated to the gap environment, observed values of quantum efficiency of $A\left(?{ }_{A}\right)$, compensation irradiance (?? and light saturated $\mathrm{A}\left(A_{\max }\right)$ varying from 0.02 to $0.04 \mu \mathrm{mol} \mathrm{CO}_{2}$ 
$\mu \mathrm{mol}$ photons ${ }^{-1}, 15.8$ to $39.4 \mu \mathrm{mol}$ photons $\mathrm{m}^{-2} \mathrm{~s}^{-1}$ and 2.2 to 10.1 $\mu \mathrm{mol} \mathrm{CO} 2 \mathrm{~m}^{-2} \mathrm{~s}^{-1}$, respectively. According to Luttige (1997), the limit values for ? and $A_{\max }$ in sun plants of tropical forests are between 20 and $30 \mu \mathrm{mol}$ photons $\mathrm{m}^{-2} \mathrm{~s}^{-1}$, and 10 and $20 \mu \mathrm{mol} \mathrm{CO}_{2} \mathrm{~m}^{-2} \mathrm{~s}^{-1}$, respectively.

The incorporation of a linear function $\left(\mathrm{y}=1-V P D_{L} / V P D_{o}\right)$ to the light response equations has been used successfully (Dolman, 1988; Dolman and Van Den Burg, 1988; McCaughey and Iacobelli, 1994; and Mielke et al., 1999) to estimate $g s$ in different tree species, being an appropriated indicator of the stomatal sensibility to $V P D_{L}$. For the adjustment of the models, 51 and 48 simultaneous readings of $A, g s, Q i$ and $V P D_{L}$ were used for MYD and BGD, respectively, with the omission of the values when $Q i=0 \mu \mathrm{mol}$ photons $\mathrm{m}^{-2} \mathrm{~s}^{-1}$. The equations obtained were the following:

For MYD:

$A=\left(((19.0 \times 0.05 Q i) /(19.0+0.05 Q i))\left(1-V P D_{L} / 10.0\right)\right)-1.78\left[\mathrm{r}^{2}=\right.$ $0.91]$, and

$g s=((0.39 \times 0.0004 Q i) /(0.39+0.0004 Q i))\left(1-V P D_{L} / 11.4\right)\left[\mathrm{r}^{2}=0.75\right]$

For BGD

$A=\left(((22.9 \times 0.07 Q i) /(22.9+0.07 Q i))\left(1-V P D_{L} / 5.5\right)\right)-1.54\left[\mathrm{r}^{2}=0.84\right]$,

and

$g s=((0.70 \times 0.002 Q i) /(0.70+0.002 Q i))\left(1-V P D_{L} / 3.6\right)\left[\mathrm{r}^{2}=0.65\right]$ 
For both genotypes, $A$ and $g s$ showed a different and negative response to the increases in $V P D_{L}$, with $g s$ ? $0 \mathrm{~mol} \mathrm{H}_{2} \mathrm{O} \mathrm{m}^{-2} \mathrm{~s}^{-1}$ when $V P D_{L}$ ? 11.4 and $3.6 \mathrm{kPa}$ for MYD and BGD, respectively. Those data indicate that MYD seems to be more capable than BGD in maintaining the stomata open under conditions of higher values of $V P D_{L}$, thereby maintaining a positive rate of carbon assimilation at the hottest hours of the day (Figure 3). The significantly higher $A / g s$ value for MYD genotype (Table 2) reinforces the idea of a higher photosynthetic efficiency to each value of stomatal conductance in that genotype.

In summary, both dwarf coconut genotypes showed high photosynthetic rates and high water use efficiency when compared with talls and hybrids genotypes. The light-response curves obtained at field conditions indicated that $A$ and $g s$ were highly dependents of $Q i$. The application of a multiplicative empirical model relating $A$ or $g s$ with $Q i$ and $V P D_{L}$, was efficient in identifying useful integrative relationships among the data, such as the negative response of the stomata to increasing $V P D_{L}$. Besides, the inclusion of a linear function relating the effects of $V P D_{L}$ on $A$ or $g s$ allowed a better use of the data collected in the field. The Malayan Yellow Dwarf genotype showed a higher photosynthetic efficiency than the Brazilian Green Dwarf for the same value of stomatal conductance, being capable of maintaining a positive rate of carbon assimilation at the hottest and more dry hours of the day.

\section{ACKNOWLEDGEMENTS}

The authors wish to thank the Director of the Experimental Station of CEPLAC, Dr. José Inácio Lacerda Moura, for the valuable 
collaboration in the collection of data in the field, and Dr. Leandro L. Loguercio for valuable comments in the manuscript. The financial support was provided by UESC. 


\section{REFERENCES}

BALL, J.T., WOODROW, I.E., BERRY, J.A. (1987) A model predicting stomatal conductance and its contribution to the control of photosynthesis under different environmental conditions. In Progress in Photosynthesis Research (J. Biggins, ed.), Dordrecht: Martinus Nijhoffpus, 4: 221-225.

BARKER, M.G., PRESS, M.C., BROWN, N.D. (1997) Photosynthetic characteristics of dipterocarp seedlings in three tropical rain forest light environments: a basis for niche partitioning? Oecologia, 112: 453-463.

BRACONIER, S. (1998) Mesure des échanges gazeux foliares chez le cocotier. Plantations, recherche, dévelopment, 5(4): 269-276.

CINTRA, F.L.D., LEAL, M.L.S. and PASSOS, E.E.M. (1992) Distribution du système racinaire des cocotiers Nains. Oleagineux, 47(5): 225-234.

DAY, M. E. (2000) Influence of temperature and leaf-to-air vapour pressure deficit on net photosynthesis and stomatal conductance in red spruce (Picea rubens). Tree Physiology, 20: 57-63.

DOLMAN, A.J. (1988) Transpiration of an oak forest as predicted from parameter and weather data. Journal of Hydrology, 97: 225-234.

DOLMAN, A.J., VAN DEN BURG, G.J. (1988) Stomatal behavior in an oak canopy. Agricultural and Forest Meteorology, 43: 99108. 
EHLERINGER, J.R., CERLING, T.E. (1955) Atmospheric $\mathrm{CO}_{2}$ and the ratio of intercellular to ambient $\mathrm{CO}_{2}$ concentrations in plants. Tree Physiology, 15: 105-111.

HOGAN, K.P., SMITH, A.P., SAMANIEGO, M. (1995) Gas exchange in six tropical semi-deciduous forest canopy tree species during wet and dry seasons. Biotropica, 27(3): 324-333.

IQBAL, R. M., RAO, A. ur-R., RASUL, E. and WAHID, A. (1997) Mathematical models and response functions in photosynthesis: an exponential model. In Handbook of photosynthesis (M. Pessarakli, Ed.), Marcel Dekker, Inc., New York, USA, 803810.

ISHIDA, A., TOMA, T., MATSUMOTO, Y., YAP, S.K., MARUYAMA, Y. (1996) Diurnal changes in leaf characteristics in the uppermost canopy of a rain forest tree, Dryobalanops aromatica Gaertn. f. Tree Physiology, 16: 779785 .

JARVIS, P.G. (1976) The interpretation of the variations in leaf water potential and stomatal conductance found in canopies in the field. Philosophical Transactions of the Royal Society, 273: 593-610.

JAYASEKARA, C and JAYASEKARA, K.S. (1995) Photosynthetic characteristics of tropical tree species with special reference to palms. Energy Convers. Mgmt., 36(6-9): 919-922.

KASTURI BAI, K. V., VOLETI, S. R. and RAJAGOPAL, V. (1988) Water relations of coconut palms as influenced by environmental variables. Agriculture, Forestry, Meteorology, 43: 193-199. 
KASTURI BAI, K. V., RAJAGOPAL, V. PRABHA, C. D., RATNAMBAL, M. J. and GEORGE, M. V. (1996) Evaluation of coconut cultivars and hybrids for dry matter production. Journal of Plantation Crops, 24: 23-28.

KASTURI BAI, K.V.; RAJAGOPAL, D.; BALASIMHA, D.; GOPALASUDARAM, P. (1997) Water relations, gas exchange and dry matter production of coconut (Cocos nucifera L.) under irrigated and non-irrigated conditions. Coconut Research and Development, 13(2): 45-58.

LEUNING, R. (1990) Modeling stomatal behaviour and photosynthesis of Eucalyptus grandis. Australian Journal of Plant Physiology, 17: 159-75.

LUTTIGE, U. (1997) Physiological ecology of tropical plants. Berlin: Springer, 384p.

MANSFIELD, T. A. and DAVIES, W. J. (1985) Mechanisms for leaf control of gas exchange. Bioscience, 35(3): 158-164.

MATHEW, C. and RAMADASAN, A. (1974) Studies on photosynthesis in coconut. Rate of apparent photosynthesis. Indian Journal of Experimental Biology, 12: 589-590.

MATHEW, C. and RAMADASAN, A. (1975) Photosynthetic efficiency in relation to annual yield and chlorophyll content in coconut palm. Journal of Plantation Crops, 3: 26-28.

McCAUGHEY, J.H., IACOBELLI, A. (1994) Modeling stomatal conductance in a northern deciduous forest, Chalk River, Ontario. Canadian Journal of Forest Research, 24: 904-910. 
MIELKE, M.S.; OLIVA, M.A.; BARROS, N.F.; PENCHEL, R.M.; MARTINEZ, C.A.; ALMEIDA, A.C. (1999) Stomatal control of transpiration in the canopy of a clonal Eucalyptus grandis plantation. Trees, 13: 152-160.

MIELKE, M.S., OLIVA, M.A., BARROS, N.F., PENCHEL, R.M., MARTINEZ, C.A., FONSECA, S., ALMEIDA, A.C. (2000) Leaf gas exchange in a clonal eucalyptus plantation as related to soil moisture, leaf water potential and microclimate variables. Trees, 14: 263-270.

PASSOS, E.E.M., SILVA, J.V. (1990) Fonctionnement des stomates de cocotier (Cocos nucifera) au champ. Canadian Journal of Botany, 68: 458-460.

PASSOS, E.E.M., PRADO, C.H.B.A. and LEAL, M.L.S. (1999) Condutância estomática, potencial hídrico foliar e emissão de folhas e inflorescências em três genótipos de coqueiro anão. Agrotrópica, 11(3): 147-152.

PRADO, C.H.B.A., PASSOS, E.E.M. and MORAES, J.A.P.V. (2001) Photosynthesis and water relation of six tall genotypes of Cocos nucifera in wet and dry seasons. South African Journal of Botany, 67: 169-176.

RAJAGOPAL, V.; KASTURI BAI, K.V. (1999) Water relations and screening for drought tolerance. In Advances in plant physiology and biochemistry of coconut palm. (V. Rajagopal and A. Ramadasan, Eds.). Jakarta: APCC, pp. 55-72. 
SHIVASHANKAR, S., KASTURI BAI, K. V. and RAMADASAN, A. (1982) A comparative study of coconut genotypes for component of photosynthesis and respiration. In Proc. Placrosym V (R.D. Iyer, Ed.), 231-234.

SHIVASHANKAR, S., KASTURI BAI, K. V. and RAJAGOPAL,V. (1991) Leaf water potential, stomatal resistance and activity of enzimes during development of moisture stress in the coconut palm. Tropical Agriculture, 68(2): 106-10.

STATSOFT, Inc. (1995) STATISTICA for Windows [Computer program manuall. Tulsa, OK, USA.

THORNLEY, J. H. M. and JOHNSON, I. R. (1990) Plant and crop modeling. A mathematical approach to plant and crop physiology. Oxford: Clarendon Press.

YANG, S., LIU, X. and TYREE, M. T. (1998) A model of stomatal conductance in sugar maple (Acer saccharum Marsh). Journal of theoretical Biology, 191(2): 197-211. 
Table 1. Mean values of microclimatic variables for Malayan Yellow Dwarf (MYD) $(\mathrm{n}=61)$ and Brazilian Green Dwarf $(\mathrm{BGD})(\mathrm{n}=49)$ coconut genotypes. $\mathrm{Ca}$, molar fraction of atmospheric $\mathrm{CQ}$; $V P D_{L}$, leaf-toair water vapour pressure deficit; $T a$, air temperature; $T f$, leaf temperature.

\begin{tabular}{ccccc}
\hline \hline Genotype & $C a\left(? \mathrm{~mol}^{\mathrm{mol}}{ }^{\mathrm{1}}\right)$ & $V P D_{L}(\mathrm{kPa})$ & $\mathrm{Ta}\left({ }^{\circ} \mathrm{C}\right)$ & $T_{L}\left({ }^{\circ} \mathrm{C}\right)$ \\
\hline MYD & $376.3(2.5)^{\mathrm{b}}$ & $1.67(0.48)^{\mathrm{a}}$ & $31.5(2.8)^{\mathrm{a}}$ & $30.3(2.6)^{\mathrm{a}}$ \\
BGD & $384.1(12.5)^{\mathrm{a}}$ & $1.38(0.25)^{\mathrm{b}}$ & $31.2(1.2)^{\mathrm{a}}$ & $29.7(1.2)^{\mathrm{a}}$
\end{tabular}

For each variable, means followed by the same letters are not different by the Tukey's procedure $(P<0.05)$.

Table 2. Mean maximum values of gas exchange parameters in two dwarf coconut genotypes for a photosynthetically active radiation incident on leaf surface $(Q i)$ ? $800 \mu \mathrm{mol} \mathrm{m} \mathrm{m}^{-2} \mathrm{~s}^{-1}$. MYD, Malayan Yellow Dwarf; BGD, Brazilian Green Dwarf; $A$, rate of net photosynthesis; $g s$, stomatal conductance to water vapour; $E$, rate of transpiration; WUEi, instantaneous water use efficiency; $\mathrm{Ci} / \mathrm{Ca}$, internal to atmospheric molar fraction of $\mathrm{CQ}$; $R d$, rate of dark respiration.

\begin{tabular}{lcc}
\hline \hline Variable & MYD $(\boldsymbol{n}=29)$ & BGD $(\mathbf{n}=\mathbf{2 0})$ \\
\hline \hline$A\left(\mu \mathrm{mol} \mathrm{CO} \mathrm{C} \mathrm{m}^{-2} \mathrm{~s}^{-1}\right)$ & $10.4(2.3)^{\mathrm{b}}$ & $12.0(2.8)^{\mathrm{a}}$ \\
$g s\left(\mathrm{~mol} \mathrm{H} \mathrm{O} \mathrm{m}^{-2} \mathrm{~s}^{-1}\right)$ & $0.21(0.10)^{\mathrm{b}}$ & $0.35(0.12)^{\mathrm{a}}$ \\
$A / g s\left(\mu \mathrm{mol} \mathrm{CO} \mathrm{mol} \mathrm{H}_{2} \mathrm{O}^{-1}\right)$ & $57.0(15.1)^{\mathrm{a}}$ & $36.2(7.2)^{\mathrm{b}}$ \\
$E\left(\mathrm{mmol} \mathrm{H}_{2} \mathrm{O} \mathrm{m}^{-2} \mathrm{~s}^{-1}\right)$ & $3.07(1.41)^{\mathrm{a}}$ & $3.69(1.03)^{\mathrm{a}}$ \\
$W U E i\left(\mu \mathrm{mol} \mathrm{CO} \mathrm{mmol} \mathrm{H}_{2} \mathrm{O}^{-1}\right)$ & $3.98(1.70)^{\mathrm{a}}$ & $3.39(0.90)^{\mathrm{a}}$ \\
$C i / C a$ & $0.66(0.05)^{\mathrm{b}}$ & $0.75(0.03)^{\mathrm{a}}$ \\
$R d\left(\mu \mathrm{mol} \mathrm{CO} \mathrm{m}^{-2} \mathrm{~s}^{-1}\right)$ & $-1.84(0.60)^{\mathrm{a}} *$ & $-1.54(0.35)^{\mathrm{a}} * *$ \\
\hline
\end{tabular}

For each variable, means followed by the same letters are not different by the Tukey's procedure $(P<0.05)$ * $(n=12) ; * *(n=8)$ 
Table 3. Parameters derived from the light response curves of the rates of net photosynthesis $(A)$ and stomatal conductance to water vapour $(g s)$ of two dwarf genotypes of coconut. MYD, Malayan Yellow Dwarf; BGD, Brazilian Green Dwarf, $A_{\max }$, light saturated rate of net photosynthesis; ? ${ }_{A}$, apparent quantum efficiency of photosynthesis; $g s_{\max }$, light saturated stomatal conductance to water vapour and? ${ }_{g s}$, apparent quantum efficiency of stomatal conductance?, compensation irradiance.

\begin{tabular}{|c|c|c|}
\hline Parameters & MYD & BGD \\
\hline$\overline{A_{\max }\left(\mu \mathrm{mol} \mathrm{CO} \mathrm{CO}_{2} \mathrm{~m}^{-2} \mathrm{~s}^{-1}\right)}$ & $\overline{19.0}$ & 22.9 \\
\hline$g s_{\max }\left(\mathrm{mol} \mathrm{H} \mathrm{O}_{2} \mathrm{~m}^{-2} \mathrm{~s}^{-1}\right)$ & 0.39 & 0.70 \\
\hline$?_{\mathrm{A}}\left(\mu \mathrm{mol} \mathrm{CO} \mathrm{CO}_{2} \mu \mathrm{mol}\right.$ photons $\left.{ }^{-1}\right)$ & 0.05 & 0.07 \\
\hline$?{ }_{\mathrm{gs}}\left(\mathrm{mol} \mathrm{H} \mathrm{H}_{2} \mathrm{O} \mu \mathrm{mol}_{\text {photons }}{ }^{-1}\right)$ & 0.0004 & 0.002 \\
\hline$?\left(\mu \mathrm{mol}\right.$ photons $\left.\mathrm{m}^{-2} \mathrm{~s}^{-1}\right)$ & 48.4 & 32.5 \\
\hline
\end{tabular}

Figure 1. Relationship between phosyntheticaly active radiation $Q i$ ) and internal to atmospheric molar fraction of $\mathrm{CQ}(\mathrm{Ci} / \mathrm{Ca})$ for two dwarf genotypes of coconut. Brazilian Green Dwarf ?) and Malayan Yellow Dwarf (?).

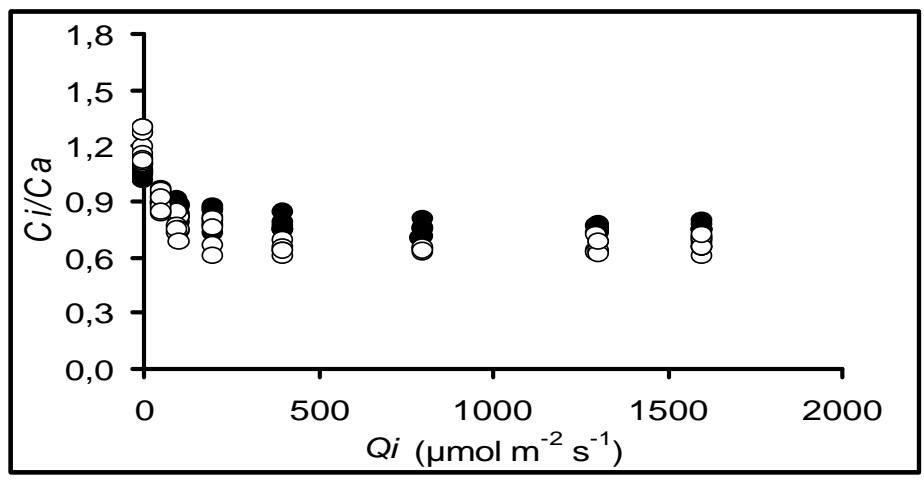

Fig 1 
Figure 2. Relationships between net photosynthesis $(A)$ and phothosyntheticaly active radiation $(Q i)$ and between stomatal conductance to water vapour $g s$ ) and $Q i$ for Brazilian Green Dwarf (?) and Malayan Yellow Dwarf (o) at field conditions. The light response curves of $A$ and $g s$ are derived of he models adjusted from the plotted values (for the equations, see text).

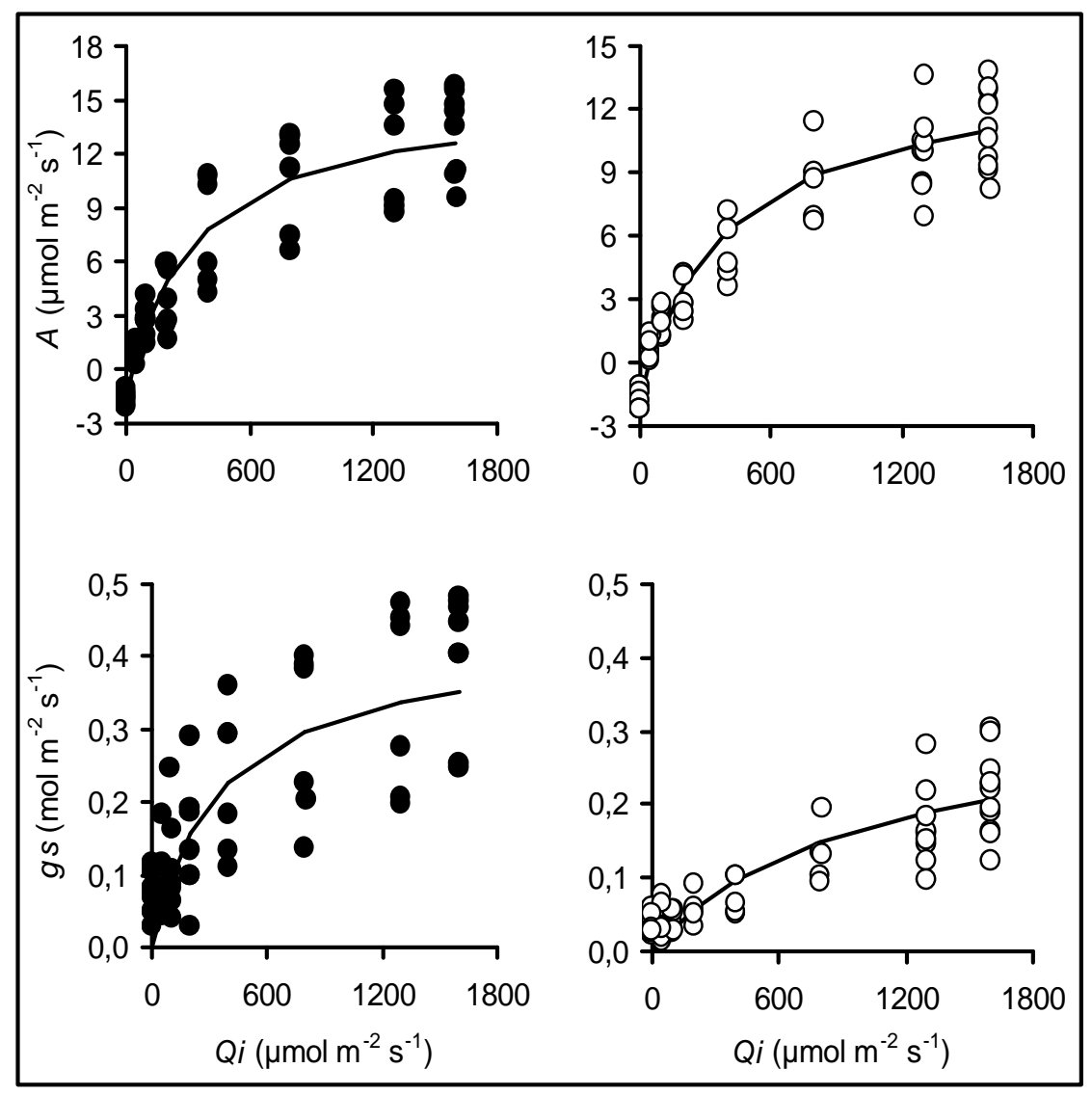

Fig 2 
Figure 3. Relationship between net photosynthesis (A) and leaf-to-air water vapour pressure deficit inside the chamber $\left.V P D_{L}\right)$ and between stomatal conductance to water vapour $(g s)$ and $V P D_{L}$ for two genotypes of coconut palm at field conditions. Brazilian Green Dwarf (?); Malayan Yellow Dwarf (o).

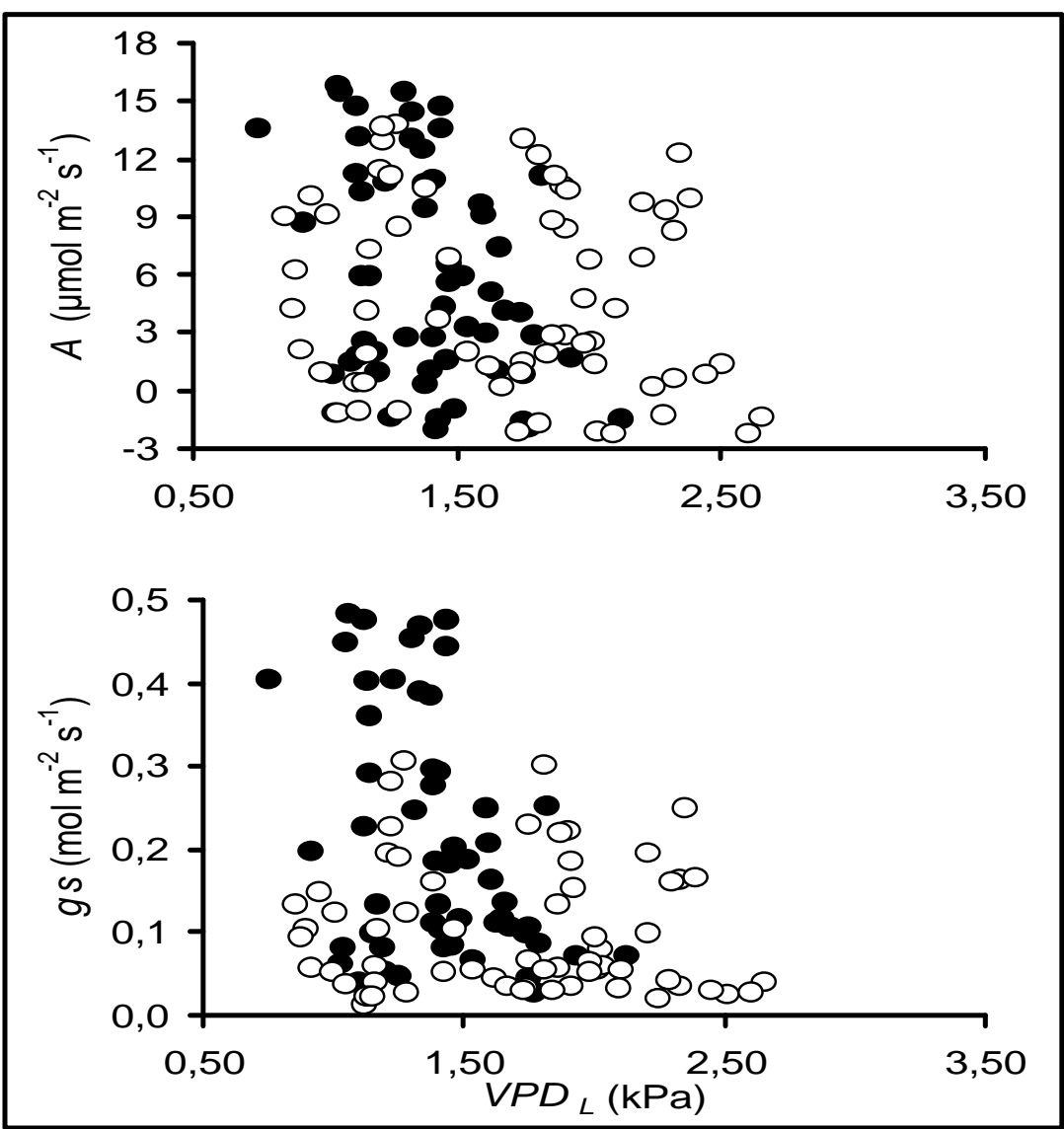

Fig 3 